\title{
AKTIVITAS ANTIBAKTERI EKSTRAK DAUN BINAHONG TERHADAP PROPIONIBACTERIUM ACNES
}

\author{
Indarto $^{1 *}$, Windy Narulita ${ }^{2}$, Bambang Sri Anggoro $^{3}$, Aulia Novitasari $^{4}$ \\ 1,2,3,4 Universitas Islam Negeri Raden Intan Lampung, Indonesia \\ "Email : indarto@radeniantan.ac.id
}

Received: Mey 11 $1^{\text {th }}$ 2019. Accepted: June 29 ${ }^{\text {th }}$, 2019. Published: June $30^{\text {th }}, 2019$

\begin{abstract}
The purpose of this study was to determine whether binahong leaf extract can inhibit the growth of Propionibacterium acnes bacteria. This study was a laboratory experimental study using a completely randomized design $(C R D)$ with five treatments. The treatment was repeated 3 times with various concentrations of $20 \%, 40 \%, 60 \%, 80 \%$, and 100\%, clindamycin as a comparison and aquadest as a control. The binahong leaf extract was obtained from maceration of binahong leaves with methanol and partitioned using ethyl acetate, then tested the antibacterial activity against Propionibacterium acnes bacteria. The parameters observed were the diameter of the zone inhibiting the growth of Propionibacterium acnes bacteria. Data analysis using Analysis of Variance (ANOVA). The result is known that binahong leaf extract has the ability to inhibit the growth of Propionibacterium acnes bacteria seen by the presence of inhibitory zones formed. The most effective concentration to inhibit the growth of Propionibacterium acnes bacteria is at a concentration of $100 \%$ at $9.00 \mathrm{~mm}$ in 24 hours and $11.20 \mathrm{~mm}$ in 48 hours.
\end{abstract}

Keywords: Binahong (Anredera cordifolia); antibacterial; Propionibacterium acnes; acne

\begin{abstract}
Abstrak
Tujuan penelitian ini adalah untuk mengetahui apakah ekstrak daun binahong dapat menghambat pertumbuhan bakteri Propionibacterium acnes. Penelitian ini merupakan penelitian eksperimental laboratorium dengan menggunakan Rancangan Acak Lengkap (RAL) dengan lima perlakuan. Perlakuan diulang sebanyak 3 kali dengan berbagai macam konsentrasi dari 20\%, 40\%, 60\%, 80\%, dan $100 \%$, serta klindamisin sebagai pembanding dan aquades sebagai kontrol. Ektrak daun binahong diperoleh dari maserasi daun binahong dengan pelarut metanol dan dipartisi dengan menggunakan pelarut etil asetat, kemudian dilakukan uji aktivitas antibakteri terhadap bakteri Propionibacterium acnes. Parameter yang diamati adalah diameter zona hambat pertumbuhan bakteri Propionibacterium acnes. Analisis data menggunakan ANOVA (Analysis of Variance). Hasilnya diketahui bahwa ekstrak daun binahong memiliki kemampuan menghambat pertumbuhan bakteri Propionibacterium acnes terlihat dengan adanya zona hambat yang terbentuk. Konsentrasi yang paling efektif menghambat pertumbuhan bakteri Propionibacterium acnes adalah pada konsentrasi 100\% sebesar 9,00 mm pada waktu 24 jam dan 11,20 mm pada waktu 48 jam.
\end{abstract}

Kata Kunci: Binahong (Anredera cordifolia); Antibakteri; Propionibacterium acnes; Jerawat.

\section{PENDAHULUAN}

Penyakit kulit merupakan suatu penyakit yang menyerang pada permukaan tubuh, dan disebabkan oleh berbagai macam penyebab yang paling umum dan menginfeksi segala macam usia. Sebagian pengobatan penyakit kulit membutuhkan waktu yang lama untuk menyebabkan efek. Beberapa makhluk hidup dapat menyebabkan penyakit kulit, seperti bakteri, virus, maupun jamur. Bakteri, virus dan jamur menginfeksi kulit sangat umum terjadi dan dapat merusak kulit tetapi tidak pernah sampai mematikan. Jerawat atau Acne 
vulgaris merupakan salah satu penyakit kulit yang banyak dijumpai secara global pada remaja dan dewasa muda.

Jerawat atau acne vulgaris adalah penyakit peradangan kronik kelenjar pilosebasea yang ditandai dengan munculnya komedo, papula, pustul, dan nodul. Organisme utama yang pada umumnya memberi kontribusi terhadap terjadinya jerawat adalah Propionibacterium acnes. Propionibacterium acnes merupakan mikroorganisme utama yang ditemukan di daerah infra infundibulum dan bakteri ini dapat mencapai permukaan kulit dengan mengikuti aliran sebum. Meningkatnya jumlah trigliserida dalam sebum akan meningkatkan jumlah Propionibacteriumacnes, karena trigliserida dalam sebum merupakannutrisi bagi Propionibacterium acnes. Propionibacterium acnes diduga berperan penting menimbulkan inflamasi pada acne vulgaris dengan menghasilkan faktor kemotaktik dan enzim lipase yang akan mengubah trigliserida menjadi asam lemak bebas, serta menstimulasi aktivasi jalur klasik dan alternatif komplemen (Bramono \& Indriatmi, 2015)

Pengobatan jerawat dilakukan dengan cara menurunkan produksi sebum, menurunkan inflamasi pada kulit, memperbaiki abnormalitas folikel dan menurunkan jumlah koloni Propionibacterium acnes atau hasil metabolismenya. Pemberian suatu zat antibakteri seperti tetrasiklin eritromisin, dan klindamisin dapat menurunkan populasi bakteri Propionibacterium acnes (H, Cahyanto, Sujarwo, \& Lestari, 2015). Penggunaan suatu antibiotik yang berlebihan, dapat menyebabkan meningkatnya resistensi bakteri terhadap suatu antibiotik tertentu (Roslizawaty, Ramadani, Fakhrurrazi, \& Herrialfian, 2013) Pengobatan penyakit infeksi yang disebabkan bakteri yang resisten terhadap antibiotik memerlukan produk baru yang memiliki potensi tinggi. Penelitian zat yang berkhasiat sebagai antibakteri perlu dilakukan untuk menemukan produk antibakteri baru yang berpotensi untuk menghambat atau membunuh bakteri yang resisten terhadap antibiotik dengan harga yang terjangkau salah satunya adalah obat-obatan tradisional(Umar, Krihariyani, \& Mutiarawati, 2012).

Salah satu alternatif yang dapat ditempuh yaitu memanfaatkan zat aktif pembunuh bakteri yang terkandung dalam tanaman obat binahong dengan nama ilmiah Anredera cordifolia dari famili Basellaceae (Silalahi, Sari, Siregar, Sinaga, \& Matari, 2016). Binahong (Anredera cordifolia) adalah tanaman obat potensial yang dapat mengatasi berbagai jenis penyakit. Tumbuhan ini berasal dari Amerika Selatan dan sudah dikenal sebagai tanaman obat di negara asalnya semenjak ratusan tahun yang lalu. Di Indonesia sendiri binahong masih baru-baru ini saja dijadikan obat alternatif untuk berbagai macam penyakit, baik penyakit ringan maupun penyakit yang berat. Daun binahong dengan pelarut etil asetat, petroleum eter, dan etanol $70 \%$ menunjukkan bahwa pada daun binahong mengandung senyawa flavonoid, alkaloid, saponin dan polifenol. Ekstrak daun binahong pernah diujikan pada bakteri gram negatif yaitu bakteri Escherichia coli dengan konsentrasi $0 \%, 25 \%, 50 \%, 75 \%$ dan $100 \%$. Hasil uji menunjukkan bahwa perasan daun binahong memiliki aktivitas antibakteri terhadap Escherichia coli secara in vitro. Hasil uji juga menunjukkan bahwa semakin tinggi konsentrasi maka akan semakin besar daya hambat terhadap pertumbuhan bakteri dan konsentrasi paling optimal yang dapat menghambat adalah konsentrasi 100\% (Ainurrochmah, Ratnasari, \& Lisdiana, 2013)

Berdasarkan beberapa penelitian yang telah dilakukan sebelumnya telah dilakukan beberapa penelitian yang membahas mengenai manfaat daun binahong (Ainurrochmah et al., 2013; Divadi \& Yuliani, 2016; Faustina \& Yuliani, 2015; Jazilah, Fasya, Ningsih, \& Abtokhi, 2014; Rimporok, Kepel, \& Siagian, 2015; Umar et al., 2012) serta beberapa penlitian dalam menghambat pertumbuhan bakteri Propionibacterium acnes (Aida, Suswati, \& Misnawi, 2016; Alfath, Yulina, \& Sunnati, 2013) Namun, belum adanya 
penelitian yang menjelaskan penggunaan ekstrak dari daun binahong (AnrederaCordifolia) untuk menghambat pertumbuhan bakteri Propionibacterium acnes secara In Vitro.

Berdasarkan penelitian terdahulu, keterbaruan penelitian ini terletak pada penjelasan penggunaan ekstrak dari daun binahong (AnrederaCordifolia) untuk menghambat pertumbuhan bakteri Propionibacterium acnes secara In Vitro. Maka, tujuan penelitian ini adalah untuk mengetahui apakah ekstrak daun binahong dapat menghambat pertumbuhan bakteri Propionibacterium acnes.

\section{METODE PENELITIAN}

Metode penelitian yang digunakan adalah penelitian eksperimental laboratorik. Uji aktivitas antibakteri dari ekstrak etil asetat daun binahong terhadap bakteri Propionibacterim acnes dilakukan secara in vitro menggunakan metode difusi sumur dengan penentuan diameter zona hambatan. Pengujian antibakteri disusun dalam Rancangan Acak Lengkap (RAL) dengan uji pada konsentrasi ekstrak etil asetat daun binahong 20\%, 40\%, 60\%, 80\%, dan 100\% serta digunakan aquades sebagai kontrol negatif dan klindamisin sebagai kontrol positif. Perlakuan diulang sebanyak 3 kali ulangan. Penelitian meliputi preparasi sampel, ekstraksi sampel, uji skrining fitokimia, sterilisasi alat dan bahan, pembuatan media, inokulasi bakteri uji, serta uji efektivitas antibakteri. Parameter yang diamati dalam penelitian ini adalah diameter zona hambat bakteri Propionibacterium acnes pada media Nutrien Agar (NA) yang diberi perlakuan dengan masing-masing konsentrasi ekstrak daun binahong. Pengukuran diameter zona hambat pertumbuhan bakteri menggunakan jangka sorong. Data dianalisis dengan menggunakan ANOVA (Analysis of Variance).

Alat- alat yang digunakan dalam penelitian ini adalah, rotary evaporator, lesung, saringan, tabung reaksi, rak tabung, cawan petri, mikro pipet, pipet ukur, kawat ose, gelas ukur, kertas saring, autoklaf, inkubator, timbangan, jangka sorong, dan kamera. Bahanbahan yang digunakan dalam penelitian ini adalah daun binahong yang diperoleh dari Desa Purwodadi Kecamatan Gisting Kabupaten Tanggamus, biakan murni bakteri Propionibacterium acnes yang diperoleh dari Politeknik Negri Lampung, aquades, medium Nutrien Broth (NB), medium Nutrien Agar (NA), metanol, etil asetat, $\mathrm{HCl}, \mathrm{FeCl}_{3}, \mathrm{HgCl}_{2}$, $\mathrm{Mg}$, betadin dan klindamisin.

Sampel berupa daun binahong diperoleh dari Desa Purwodadi Kecamatan Gisting Kabupaten Tanggamus. Daun yang dipilih harus daun yang segar dan sehat. Daun binahong lalu dibersihkan dan dipotong kecil-kecil, kemudian dikeringkan dengan cara dianginanginkan. Hasil pengeringan ini disebut dengan simplisia.

\section{Pembuatan Ekstrak}

Sebanyak 300 gram daun binahong kering dibuat ekstrak dengan menggunakan metode maserasi. Proses maserasi dilakukan menggunakan metanol. Maserasi dilakukan sebanyak tiga kali. Ekstrak metanol yang diperoleh disaring, dan diperoleh ekstrak kasar sebanyak $500 \mathrm{~mL}$. Kemudian ekstrak kasar tersebut dipekatkan dengan menggunakan rotaryevaporator sehingga diperoleh ekstrak kental(ekstrak metanol) sebanyak $100 \mathrm{~mL}$. Ekstrak metanol yang diperoleh dipartisi dengan menggunakan etil asetat dalam corong pisah dengan perbandingan 1:1. Kemudian dikocok, lalu didiamkan beberapa saat hingga terbentuk pemisahan lalu dipisahkan dan ditampung hasil partisisnya. Ekstrak etil asetat berada di bagian bawah karena massa jenis etil asetat lebih besar dari massa jenis metanol. Selanjutnya dari hasil partisi diperoleh ekstrak etil asetat sebanyak $300 \mathrm{~mL}$. Kemudian 
ekstrak tersebut dipekatkan kembali dengan menggunakan rotary evaporator. Setelah didapatkan ekstrak pekat, lalu diencerkan dengan pengenceran $20 \%, 40 \%, 60 \%$, $80 \%$, dan $100 \%$.

\section{Persiapan Media Nutrient Broth ( NB) dan Nutrient Agar ( NA)}

Pembuatan media NB dilakukan dengan cara menimbang sebanyak 3.25 gram NB. Kemudian dimasukkan ke dalam labu erlenmeyer lalu ditambahkan dengan $250 \mathrm{ml}$ aquades. NB dan aquades dalam labu erlenmeyer dipanaskan dengan menggunkan hotplate selama \pm 10 menit hingga NB larut.

Pembuatan media NA dilakukan dengan cara menimbang sebanyak 7,25 gram NA. Kemudian dimasukkan ke dalam labu erlenmeyer lalu ditambahkan dengan $250 \mathrm{ml}$ aquades. NA dan aquades dalam labu erlenmeyer dipanaskan dengan menggunkan hotplate selama \pm 10 menit hingga NA larut. Media yang telah homogen disterilisasi di dalam autoklaf selama 15 menit pada suhu $121^{\circ} \mathrm{C}$. Setelah itu media ditunggu hingga agak dingin sekitar suhu $40-45^{\circ} \mathrm{C}$. Media NA yang telah dingin kemudian nantinya akan dituangkan ke cawan petri sebanyak $20 \mathrm{~mL}$. Media NA yang telah dituang ke dalam cawan petri dibiarkan hingga memadat.

\section{Inokulasi Bakteri Uji}

Bakteri yang digunakan dalam penelitian ini adalah bakteri $P$. acnes yang diperoleh dari Laboratorium Tekhnologi Hasil Pertanian Politeknik Negri Lampung. Inokulasi bakteri dilakukan dengan menggunakan metode tuang (poured plate). Sebelum dipakai dalam ujiantibakteri, bakteri yang akan dipakai setiap kali harus diregenerasi terlebih dahulu dari medium yang lama ke medium yang baru. Biakan bakteri yang akan diuji ditanam satu ose pada $10 \mathrm{~mL}$ media Nutrient Broth (NB), kemudian diinkubasi selama 48 jam. Setelah itu dari biakan tersebut diambil $0,1 \mathrm{~mL}$ dan dituangkan pada $250 \mathrm{~mL}$ media NA. Selanjutnya NA dituangkan pada cawan petri yang masing-masing cawan berisi $\pm 20 \mathrm{~mL}$ media NA.

\section{Uji Aktivitas Antibakteri}

Pengujian aktivitas antibakteri ekstrak daun binahong menggunakan metode difusi agar dengan teknik sumur (cup plate technique). Uji aktivitas antibakteri dilakukan dengan cara membuat sumuran pada media NA (diameter sumuran $\pm 6,7 \mathrm{~mm}$ ) pada media Nutrient Agar yang sudah ditanam dengan bakteri uji. Setiap cawan dibuat 3 sumuran menggunakan tip mikro pipet, kemudian pada setiap sumuran dimasukkan ekstrak daun binahong dengan konsentrasi yang berbeda. Klindamisin digunakan sebagai uji kontrol positif sedangkan uji kontrol negatif menggunakan aquades steril. Media yang sumurannya telah ditetesi dengan larutan uji kemudian diinkubasi pada suhu $37^{\circ} \mathrm{C}$ selama 2 kali 24 jam dalam kondisi anaerob. Setelah diinkubasi maka dilakukan pengukuran zona hambat dengan menggunakan jangka sorong.

\section{HASIL PENELITIAN DAN PEMBAHASAN}

Sebelum sampel diekstraksi, sampel dicuci dahulu, kemudian dikeringkan menjadi simplisa, dibuat menjadi serbuk, selanjutnya diekstrak dengan menggunakan pelarut metanol dan etil asetat. Sampel dicuci bertujuan untuk membersihkan sampel dari kotoran yang melekat pada daun. Kemudian sampel dikeringkan dengan cara diangin-anginkan. Tujuan dari pengeringan adalah agar untuk menghindari pembusukan dan pertumbuhan jamur pada sampel yang dapat merubah kandungan senyawa kimia yang ada di dalamya. Proses penjemuran tidak boleh di bawah sinar matahari langsung karna dapat 
mengakibatkan senyawa-senyawa kimia yang terkandung di dalamnya teroksidasi dan mengubah kandungan dari senyawa-senyawa tersebut. Setelah kering sampel ditumbuk hingga halus. Serbuk daun binahong yang telah halus kemudian ditimbang sebanyak 300 gram, yang selanjutnya dibuat ekstrak dengan menggunakan metode maserasi. Serbuk daun binahong kemudian dipindahkan ke dalam tabung. Cara pengolahan tanaman obat, termasuk binahong dapat dilakukan dengan metode ekstraksi. Ekstraksi merupakan proses pemisahan zat dari pelarutnya sehingga kita memperoleh suatu zat tertentu yang kita inginkan. Dalam proses ekstraksi tanaman obat ini zat yang kita peroleh yaitu zat aktif dalam tanaman obat yang dapat digunakan sebagai obat untuk suatu penyakit.

Metode yang digunakan dalam proses ekstraksi ini adalah metode maserasi dan partisi menggunakan pelarut organik. Penggunaanmetode maserasi didasarkan pada praktisnya pengerjaan dan alat yang digunakan sederhana dan mudah. Tetapi kelemahannya adalah waktu pengerjaannya yang membutuhkan waktu lama. Maserasi dilakukan dengan cara merendam serbuk simpilisia dalam cairan penyari. Cairan penyari akan menembus dinding sel dan masuk ke dalam rongga sel yang mengandung zat aktif akan larut dan karena adanya perbedaan konsentrasi antara larutan zat aktif di dalam sel dengan yang di luar sel, maka larutan yang pekat akan terdesak keluar. Peristiwa tersebut berulang sehingga terjadi keseimbangan antara larutan di luar sel dan di dalam sel.

Pelarut yang digunakan adalah pelarut metanol dan etil asetat. Penggunaan pelarut yang sesuai dalam melakukan ekstraksi juga sangat penting dalam melakukan ekstraksi ini, karena dengan pelarut yang benar dapat mengikat zat-zat aktif yang terkandung dalam tanaman tersebut. Pemilihan metanol dan etil asetat sebagai pelarut, dikarenakan metanol merupakan pelarut polar sedangkan etil asetat adalah pelarut semipolar. Dalam partisi proses pemisahan komponen-komponen dalam suatu senyawa berdasarkan perbedaan kelarutan dengan prinsip, yaitu distribusi zat terlarut dalam dua pelarut yang tidak saling bercampur.

Pemilihan pelarut metanol dan etil asetat untuk mendapatkan metabolit sekunder dari daun binahong karena pelarut metanol merupakan pelarut polar yang selektif, sehingga dengan menggunakan metanol diharapkan metabolit sekunder yang ada di dalam simplisia sebagian besar terambil,dan juga pelarut metanol palingbanyak digunakan dalam proses isolasi senyawa organik bahan alam.Sedangkan pada proses partisi menggunakan pelarut etil asetat. Pemilihan etil asetat karena etil asetat sifatnya semipolar yang dapat melarutkan senyawa semipolar pada dinding sel seperti flavonoid. Di samping itu, etil asetat digunakan sebagai pelarut karena etil asetat dapat menyari senyawa-senyawa yang memberikan aktivitas antibakteri, diantaranya flavonoid dan fenol.

Analisis Fenolik dan Daya Hambat Daun Binahong (Anredera cordifolia (Ten.) steenis) terhadap bakteri Eschericia coli dan Staphylococcus aureus menunjukkan hasil yang terbaik dibandingkan ekstrak etanol terhadap bakteri Eschericia coli. Pemilihan etil asetat didasarkankarena etil asetat merupakan pelarut yang bersifat semipolar. Sifat inilah yang menyebabkan ekstrak etil asetat memiliki dua sifat kelarutan yaitu hidrofilik dan lipofilik. Diketahui pula bahwa suatu senyawa yang mempunyai polaritas optimum seperti etil asetat akan mempunyai aktivitas antimikroba maksimum, karena untuk interaksi suatu senyawa antibakteri dengan bakteri diperlukan keseimbangan hidrofilik-lipofilik.

Proses maserasi dengan pelarut metanol dilakukan selama 3 x 24 jam. Hal ini bertujuan untuk memaksimalkan proses pengambilan senyawa-senyawa kimia yang terdapat pada sampel daun. Selama proses perendaman, sampel disimpan dalam wadah 
yang tertutup dan terlindung dari cahaya langsung yang bertujuan untuk mencegah reaksi katalisis cahaya ataupun perubahan warna.

Dilakukan juga penggantian pelarut setiap hari sehingga kandungan senyawa metabolit sekunder pada sel daun binahong dapat terekstrak secara keseluruhan hingga warna maserat mulai memudar dan diperoleh maserat metanol yang maksimal. Ekstrak metanol yang diperoleh kemudian disaring, dan diperoleh ekstrak kasar etanol kemudian ekstrak kasar dipekatkan menggunakan rotary evaporator sehingga diperoleh ekstrak kental (ekstrak metanol). Ekstrak metanol yang diperoleh selanjutnya dipartisi.

Partisi dilakukan dengan menggunakan etilasetat dalam corong pisah, tunggu beberapa saatkemudian dikocok, lalu didiamkan beberapa saat hingga terbentuk pemisahan berupa 2 lapisan. Ekstrak etil asetat berada di bagian bawah karena massa jenis etil asetat lebih besar dari massa jenis metanol. Kemudian ekstrak tersebut dipekatkan kembali dengan menggunakan rotary evaporator.

Pengujian kandungan fitokimia pada ekstrak daun binahong dilakukan untuk mengetahui golongan metabolit sekunder yang terdapat pada ekstrak. Hasil penapisan fitokimia yang dilakukan pada ekstrak daun binahong diidentifikasi adanya tannin, flavonoid, saponin dan fenol. Efek antibakteri terhadap ekstrak adalah karena adanya senyawa-senyawa tersebut, senyawa aktif berupa, tannin, flavonoid, saponin dan fenol adalah senyawa yang berperan utama dalam membunuh bakteri patogen.

Tabel 1. Hasil Uji Skrining Fitokimia Daun Binahong

\begin{tabular}{cc}
\hline Golongan Senyawa & Hasil \\
\hline Alkaloid & - \\
Tanin & + \\
Flavonoid & + \\
Saponin & + \\
Fenol & + \\
\hline
\end{tabular}

Hasil menunjukan bahwa ekstrak daun binahong (Anredera cordifolia) positif mengandung senyawa flavonoid, fenol, tannin, dan saponin. Hasil pengamatan berupa perubahan warna, terbentuknya buih dan endapan yang disebabkan karena adanya reaksi antara senyawa metabolit pada ekstrak dan pereaksi.

Uji flavonoid dilakukan dengan cara menambahkan ekstrak daun binahong dengan magnesium $(\mathrm{Mg})$ dan asam klorida $(\mathrm{HCl})$ pekat yang kemudian disebut sebagai pereaksi shinoda. Sehingga dalam uji flavonoid menghasilkan warna merah. Kemudian pada uji senyawa fenol menggunakan pereaksi $\mathrm{FeCl}_{3} 1 \%$ (Indarto, 2015). Uji fenol yang dilakukan pada ekstrak daun binahong (Anrederacordifolia) memberikan hasil yang positif dengan hasil pengamatan terbentuknya warna hitam kecoklatan.

Selanjutnya pada uji senyawa tannin pereaksi yang digunakan sama dengan pereaksi yang digunakan untuk uji senyawa fenol yaitu $\mathrm{FeCl}_{3}$ namun dengan konsentrasi yang berbeda yaitu 5\%. Hasil pengamatan menunjukkan terbentuknya warna hitam pada ekstrak. Ini menandakan bahwa ekstrak daun binahong (Anredera cordifolia) positif mengandung senyawa tannin. Uji senyawa saponin memberikan hasil yang positif setelah dilakukan pengocokan pada sampel ekstrak daun binahong (Anrederacordifolia), menghasilkan busa setinggi $2 \mathrm{~cm}$.

Hasil uji alkaloid pada ekstrak daun binahong (Anredera cordifolia) menghasilkan hasil yang negatif, karena setelah pereaksi ditambahkan pada ekstrak daun binahong 
(Anredera cordifolia) tidak menghasilkan endapan berwarna putih. Hasil negatif ini kemungkinan disebabkan karena ekstrak daun binahong (Anredera cordifolia) tidak mengandung senyawa alkaloid dan juga dapat disebabkan karna pada pengujian senyawa alkaloid pereaksi mayer yang dibuat seharusnya menggunakan kalium iodida (KI) bukan betadin. Namun karena keterbatasan bahan KI diganti dengan betadin. Betadin dipilih menjadi pengganti karena larutannya mengandung senyawa KI.

Metode yang digunakan dalam proses ekstraksi ini adalah metode maserasi dan partisi menggunakan pelarut organik. Penggunaan metode maserasi didasarkan pada praktisnya pengerjaan dan alat yang digunakan sederhana dan mudah. Tetapi kelemahannya adalah waktu pengerjaannya yang membutuhkan waktu lama. Maserasi dilakukan dengan cara merendam serbuk simpilisia dalam cairan penyari. Cairan penyari akan menembus dinding sel dan masuk ke dalam rongga sel yang mengandung zat aktif akan larut dan karena adanya perbedaan konsentrasi antara larutan zat aktif di dalam sel dengan yang di luar sel, maka larutan yang pekat akan terdesak keluar. Peristiwa tersebut berulang sehingga terjadi keseimbangan antara larutan di luar sel dan di dalam sel.

Pelarut yang digunakan adalah pelarut metanol dan etil asetat. Penggunaan pelarut yang sesuai dalam melakukan ekstraksi juga sangat penting dalam melakukan ekstraksi ini, karena dengan pelarut yang benar dapat mengikat zat-zat aktif yang terkandung dalam tanaman tersebut. Pemilihan metanol dan etil asetat sebagai pelarut, dikarenakan metanol merupakan pelarut polar sedangkan etil asetat adalah pelarut semipolar. Dalam partisi proses pemisahan komponen-komponen dalam suatu senyawa berdasarkan perbedaan kelarutan dengan prinsip, yaitu distribusi zat terlarut dalam dua pelarut yang tidak saling bercampur.

Pemilihan pelarut metanol dan etil asetat untuk mendapatkan metabolit sekunder dari daun binahong karena pelarut metanol merupakan pelarut polar yang selektif, sehingga dengan menggunakan metanol diharapkan metabolit sekunder yang ada di dalam simplisia sebagian besar terambil. Dan juga pelarut metanol palingbanyak digunakan dalam proses isolasi senyawa organik bahan alam.

Sedangkan pada proses partisi menggunakan pelarut etil asetat. Partisi adalah suatu proses pemisahan komponen-komponen dalam suatu senyawa berdasarkan perbedaan kelarutan atau dalam dua macam pelarut yang tidak saling bercampur. Proses distribusi ini berdasarkan prinsip like dissolve like, yaitu senyawa yang polar akan lebih mudah larut dalam pelarut yang polar dan sebaliknya.

Pemilihan etil asetat karena etil asetat sifatnya semipolar yang dapat melarutkan senyawa semipolar pada dinding sel seperti flavonoid,. Di samping itu, etil asetat digunakan sebagai pelarut karena etil asetat dapat menyari senyawa-senyawa yang memberikan aktivitas antibakteri, diantaranya flavonoid dan fenol.

Seperti pada penelitan Hasri, dkk mengenai Analisis Fenolik dan Daya Hambat Daun Binahong (Anredera cordifolia (Ten.) steenis) terhadap bakteri Eschericia coli dan Staphylococcus aureus. Berdasarkan hasilpengujian, aktivitas antibakteri ekstrak etil asetat daun binahong menunjukkan hasil yang terbaik dibandingkan ekstrak etanol terhadap bakteri Eschericia coli. Pemilihan etil asetat didasarkankarena etil asetat merupakan pelarut yang bersifat semipolar. Sifat inilah yang menyebabkan ekstrak etil asetat memiliki dua sifat kelarutan yaitu hidrofilik dan lipofilik. Diketahui pula bahwa suatu senyawa yang mempunyai polaritas optimum seperti etil asetat akan mempunyai aktivitas antimikroba maksimum, karena untuk interaksi suatu senyawa antibakteri dengan bakteri diperlukan keseimbangan hidrofilik-lipofilik. 
Proses maserasi dengan pelarut metanol dilakukan sebanyak 3 x 24 jam. Hal ini bertujuan untuk memaksimalkan proses pengambilan senyawa-senyawa kimia yang terdapat pada sampel daun. Selama proses perendaman, sampel disimpan dalam wadah yang tertutup dan terlindung dari cahaya langsung yang bertujuan untuk mencegah reaksi katalisis cahaya ataupun perubahan warna.

Dilakukan juga penggantian pelarut setiap hari sehingga kandungan senyawa metabolit sekunder pada sel daun binahong dapat terekstrak secara keseluruhan hingga warna maserat mulai memudar dan diperoleh maserat metanol yang maksimal. Ekstrak metanol yang diperoleh kemudian disaring, dan diperoleh ekstrak kasar etanol kemudian ekstrak kasar dipekatkan menggunakan rotary evaporator sehingga diperoleh ekstrak kental (ekstrak metanol). Ekstrak metanol yang diperoleh selanjutnya dipartisi.

Partisi dilakukan dengan menggunakan etilasetat dalam corong pisah, tunggu beberapa saatkemudian dikocok, lalu didiamkan beberapa saat hingga terbentuk pemisahan berupa 2 lapisan. Ekstrak etil asetat berada di bagian bawah karena massa jenis etil asetat lebih besar dari massa jenis metanol. Kemudian ekstrak tersebut dipekatkan kembali dengan menggunakan rotary evaporator.

Pengujian kandungan fitokimia pada ekstrak daun binahong dilakukan untuk mengetahui golongan metabolit sekunder yang terdapat pada ekstrak. Hasil penapisan fitokimia yang dilakukan pada ekstrak daun binahong diidentifikasi adanya tannin, flavonoid, saponin dan fenol. Efek antibakteri terhadap ekstrak adalah karena adanya senyawa-senyawa tersebut, senyawa aktif berupa, tannin, flavonoid, saponin dan fenol adalah senyawa yang berperan utama dalam membunuh bakteri patogen.

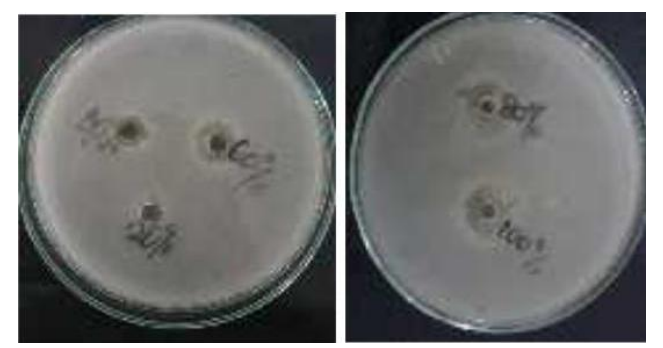

Gambar 1. Zona Hambat Ektrak Daun Binahong

Tabel 2. Data Hasil Pengamatan Zona Hambat Ektrak Daun Binahong

\begin{tabular}{lll}
\hline \multirow{2}{*}{\multicolumn{1}{c}{ Perlakuan }} & \multicolumn{2}{c}{ Diameter Zona Hambat (mm) } \\
\cline { 2 - 3 } & \multicolumn{1}{c}{ 24 Jam } & \multicolumn{1}{c}{ 48 Jam } \\
\hline Kontrol + (klindamisin) & $24.05^{\mathrm{a}} \pm 0.901$ & $35,47^{\mathrm{a}} \pm 2,61$ \\
Kontrol - & $0.00^{\mathrm{b}} \pm 0.00$ & $0,00^{\mathrm{b}} \pm 0,00$ \\
Konsentrasi 20\% & $1.13^{\mathrm{c}} \pm 0.306$ & $3.50^{\mathrm{c}} \pm 0.889$ \\
Konsentrasi 40\% & $3.63^{\mathrm{d}} \pm 1.041$ & $4.90^{\mathrm{d}} \pm 1.735$ \\
Konsentrasi 60\% & $7.50^{\mathrm{e}} \pm 1.646$ & $10.23^{\mathrm{e}} \pm 3.774$ \\
Konsentrasi $80 \%$ & $8.17^{\mathrm{f}} \pm 1.55$ & $10.83^{\mathrm{f}} \pm 0.85$ \\
Konsentrasi 100\% & $9.00^{\mathrm{g}} \pm 2.166$ & $11.20^{\mathrm{g}} \pm 0.70$ \\
\hline
\end{tabular}

Hasil uji aktivitas antibakteri daun binahong terbukti dapat menghambat pertumbuhan bakteri Propionibacterium acnes dengan dibentuknya zona bening di 
sekeliling lubang. Zona bening yang dibentuk merupakan zona hambat bagi pertumbuhan bakteri. Hal ini terjadi karena adanya aktivitas antibakteri pada daun binahong.

Pemberian konsentrasi ekstrak yang berbeda pada daun binahong menimbulkan hasil yang berbeda juga. Pada konsentrasi $20 \%$ diameter daerah hambat ekstrak daun binahong adalah $1,13 \mathrm{~mm}$, sedangkan pada konsentrasi $40 \%$ diameter daerah hambat ekstrak daun binahong adalah $3,63 \mathrm{~mm}$, pada konsentrasi $60 \%$ diameter daya hambat ekstrak daun binahong memiliki peningkatan yang sangat terlihat yaitu $7,50 \mathrm{~mm}$, sedangkan pada konsentrasi $80 \%$ dan $100 \%$ ekstrak daun binahong adalah $8,17 \mathrm{~mm}$ dan $9,00 \mathrm{~mm}$.

Pengamatan hari kedua pada waktu 48 jam menunjukan adanya peningkatan Diameter Daerah Hambat terhadap pertumbuhan bakteri Propionibacterium acnes. Terlihat pada Tabel 2yang menunjukan Diameter Daerah Hambat (DDH) bakteri semakin luas. Ini dapat dilihat dari pemberian konsentrasi $20 \%$ pada respon hambat pada waktu 24 jam daerah hambat perkembangan bakteri sebesar $1,13 \mathrm{~mm}$ sedangkan pada waktu 48 jam daerah hambat perkembangan bakteri meningkat menjadi 3,50 $\mathrm{mm}$. Perlakuan konsentrasi $40 \%$ menghasilkan respon hambat sebesar 3,63 mm pada waktu 24 jam, kemudian meningkat menjadi 4,90 mm pada waktu 48 jam.

Pada konsentrasi $60 \%$ daerah hambat pertumbuhan bakteri pada waktu 24 jam sebesar 7,50 $\mathrm{mm}$ dan meningkat menjadi $10,23 \mathrm{~mm}$ pada waktu 48 jam. Perlakuan konsentrasi $80 \%$ daerah hambat pertumbuhan bakteri pada waktu 24 jam sebesar $8,17 \mathrm{~mm}$ dan meningkat menjadi 10,23 pada waktu 48 jam. Konsentrasi $100 \%$ daerah hambat pertumbuhan bakteri pada waktu 24 jam sebesar 9,00 dan meningkat menjadi 10,20 pada waktu 48 jam.

Pembanding (kontrol positif) yang digunakan dalam penelitian ini yaitu dengan menggunakan klindamisin dan kontrol negative menggunakan aquades. Pada Tabel 2 dapat terlihat bahwa pada klindamisin zona hambat yang terukur lebih besar dibandingkan dengan ekstrak daun binahong dan aquades. Hal tersebut menunjukan klindamisin mengandung antibakteri yang sangat kuat karena klindamisin sangat aktif terhadap bakteri gram positif. Klindamisin memiliki mekanisme aksi yang sama dengan eritromisin. Mekanisme resistensinya pun sama dengan eritromisin tetapi tidak menimbulkan resistensi silang. Clostridium difficile resisten terhadap klindamisin.

Adanya zona hambat yang terbentuk karena adanya senyawa antibakteri pada daun binahong. Berdasarkan hasil uji fitokimia, senyawa metabolit sekunder yang ada pada ekstrak daun binahong (Anredera cordifolia) antara lain fenol, flavonoid, tanin dan saponin. Mekanisme penghambatan pertumbuhan bakteri oleh golongan senyawa fitokimia memiliki aktivitas yang berbeda-beda.

Senyawa fenolik bekerja dengan mengubah permeabilitas membran sitoplasma, menyebabkan kebocoran bahan-bahan intraseluler. Senyawa ini juga mendenaturasi dan menginaktifkan protein seperti enzim. Flavonoid berfungsi sebagai zat antibiotik, misalnya antivirus dan antijamur, peradangan pembuluh darah dan dapat digunakan sebagai racun ikan. Selain itu, flavonoid juga berperan langsung sebagai antibiotik dengan mengganggu fungsi dari mikroorganisme, seperti bakteri atau virus.

Mekanisme penghambatan flavonoid terhadap pertumbuhan bakteri karena kemampuan senyawa tersebut membentuk kompleks dengan protein ekstraseluler, mengaktivasi enzim, dan merusak membran sel. Pada umumnya, senyawa flavonoid dapat menghambat pertumbuhan bakteri Gram positif dan Gram negatif. Flavonoid dapat 
berfungsi sebagai bahan antimikroba dengan membentuk ikatan kompleks dengan dinding sel dan merusak membran.

Senyawa tanin memiliki mekanisme mengkoagulasi dan mendenaturasi protein. Tanin berikatan dengan protein membentuk ion $\mathrm{H}^{+}$dan mengakibatkan $\mathrm{pH}$ menjadi asam sehingga protein terdenaturasi. Kondisi asam menginaktif enzim pada bakteri dan menyebabkan metabolisme terganggu dan kerusakan sel bahkan kematian. Tanin dapat menghambat enzim reverse transcriptase dan DNA topoisomerase, sehingga sel bakteri tidak dapatterbentuk.

Hasil analisis data dengan menggunakan ANOVA (Analysis Of Variance). Pengamatan dilakukan setiap 24 jam selama 2 hari. Pada pengamatan 24 jam pertama dan 24 jam kedua, terlihat Diameter Daerah Hambat (DDH) yang berbeda nyata dengan kelompok kontrol. Tabel 2 menunjukkan bahwa uji efektivitas ekstrak etil asetat daun binahong (Anredera cordifolia) sebagai penghambat pertumbuhan bakteri Propionibacterium acnes secara in vitro berbedanyata dengan nilai signifikasi 0,000 . Hal ini menyatakan bahwa $\mathrm{H}_{0}$ ditolak dan $\mathrm{H}_{1}$ diterima sehingga dapat dikatakan ekstrak daun binahong (Anredera cordifolia) memiliki pengaruh dalammenghambat pertumbuhan bakteri $P$. acnes. Pembanding yang digunakan dalam penelitian ini yaitu dengan menggunakan klindamisin dan kontrol menggunakan aquades.

Pada Tabel 2 pada DDH 24 jam menunjukan bahwa uji efektivitas ekstrak etilasetat daun binahong (Anredera cordifolia) secara in vitro dengan nilai signifikasi 0,000 . Perlakuanekstrak yang berbeda pada daun binahong (Anredera cordifolia) menimbulkan hasil yangberbeda juga. Perlakuan konsentrasi ekstrak daun binahong masing-masing $20 \%$, 40\%, 60\%, 80\% dan 100\% yang menunjukan perbedaan yang mencolok.

Pada Tabel 2 DDH 48 jam menunjukan bahwa uji efektivitas ekstrak etil asetat daun binahong (Anredera cordifolia) secara in vitro dengan nilai signifikasi 0,000. Perlakuan ekstrak yang berbeda pada daun binahong (Anrederacordifolia) menimbulkan hasil yang berbeda juga.Perlakuan konsentrasi ekstrak daun binahong masing-masing $20 \%$, $40 \%, 60 \%, 80 \%$ dan $100 \%$ yang menunjukan perbedaan yang mencolok. Akan tetapi pada konsentrasi $60 \%$ dan $80 \%$ tidak berbeda secara signifikan namun berbeda secara signifikan dengan perlakuan lainnya.

Perlakuan kontrol positif menggunakan klindamisin memiliki nilai rata-rata yang berbeda signifikan dengan perlakuan lainnya. Perlakuan kontrol negatif yaitu menggunakan aquades steril juga berbeda secara signifikan dengan perlakuan lainnya. Perlakuan kontrol positif tidak terbentuk adanya zona hambat. Karena tidak terdapat zona bening disekitar lubang. Hal ini menunjukkan bahwa aquades tidak mempunyai sifat antibakteri karena tidak memberikan pengaruh terhadap pertumbuhan bakteri Propionibacterium acnes.

Berdasarkan uji statistik yang telah dilakukan, dapat dikatakan bahwa ekstrak daun binahong (Anredera corddifolia) dapat menghambat pertumbuhan bakteri Propionibacterium acnes secara in vitro menunjukan peningkatan rata-rata daerah hambat pada waktu 24 jam dan 48 jam. Rata-rata terendah perlakuan pada konsentrasi $20 \%$. Sedangkan rata-rata tertinggi pada konsentrasi $100 \%$.

Jika dilihat secara keseluruhan dari pengamatan hari pertama hingga hari kedua diameter daerah hambat daun binahong semakin bertambah. Ini menunjukan bahwa uji efektifitas ekstrak daun binahong (Anredera cordifolia) sangat dipengaruhi oleh waktu, semakin lama waktunya maka daerah hambat perkembangan bakteri akan semakin terhambat. Pemberian konsentrasi yang berbeda-beda menunjukkan pengaruh yang berbeda 
pula terhadap zona hambatan yang dihasilkan. Semakin tinggi konsetrasi ekstrak maka akan semakin besar daya hambat antibakteri tersebut. Semakin luas daerah zona hambatan yang terbentuk disekitar sumur, maka semakin besar pula daya antibakteri yang terdapat pada ekstrak daun binahong.

Aktivitas antibakteri juga dipengaruhi oleh beberapa faktor antara lain kandungan zat antibakteri, jenis bakteri yang dihambat, waktu inkubasi, pelarut yang digunakan pada saat pembuatan ekstrak, dan juga kemampuan suatu bahan antimikroba dalam meniadakan kemampuan hidup mikroorganisme tergantung pada besarnya konsentrasi ekstrak tersebut.

\section{SIMPULAN DAN SARAN}

Berdasarkan hasil dan pembahasan maka dapat disimpulkan bahwa ekstrak etil asetat daun binahong (Anrederacordifolia) memiliki aktivitas anti bakteri dalam menghambat pertumbuhan bakteri Propionibacterium acnes secara in vitro.

Adapun saran dari penelitian yang telah dilakukan yaitu agar peneliti selajutnya dapat melakukan penelitian mengenai pemanfaatan ekstrak daun binahong dalam hal yang lainnya.

\section{DAFTAR PUSTAKA}

Aida, A. N., Suswati, E., \& Misnawi. (2016). Uji In Vitro Efek Ekstrak Etanol Biji Kakao (Theobroma cacao) sebagai Antibakteri terhadap Propionibacterium acnes. E-Jurnal Pustaka Kesehatan, 4(4).

Ainurrochmah, A., Ratnasari, E., \& Lisdiana, L. (2013). Efektivitas Ekstrak Daun Binahong (Anredera cordifolia) terhadap Penghambatan Pertumbuhan Bakteri Shigella flexneri dengan Metode Sumuran. Lentera Bio, 2(3).

Alfath, C. R., Yulina, V., \& Sunnati. (2013). Antibacterial Effect of Granati fructus Cortex Extract on Streptococcus mutans In Vitro. Journal of Dentistry Indonesia, 20(1).

Bramono, S. L. S. M. K., \& Indriatmi, W. (2015). Ilmu Penyakit Kulit dan Kelamin. Jakarta: Fakultas KedokteranUniversitas Indonesia.

Divadi, A., \& Yuliani, S. H. (2016). Pembuatan dan uji aktivitas sediaan gel scarless wound dengan ekstrak daun binahong dan zat aktif piroxicam. Jurnal Farmasi Sains Dan Komunitas, 12(2), 41-47.

Faustina, M., \& Yuliani, S. H. (2015). Pembuatan dan Uji Aktivitas dengan Unguenta Scarless Wound dengan Ekstrak Binahong dan Zat Aktif Aspirin. Jurnal Farmasi Sains Dan Komunitas, 12(2), 81-87.

H, A. R., Cahyanto, T., Sujarwo, T., \& Lestari, R. I. (2015). Uji Aktivitas Antibakteri Ekstrak Daun Beluntas ( Pluchea Indica (L.) Less. ) Terhadap Propionibacterium Acnes PenyebabJerawat. Research Gate, 9(1).

Indarto. (2015). Uji Kualitatif dan Kuantitatif Golongan Senyawa Organik dari Kulit dan Kayu Batang Tumbuhan Artocarpus. Al-Biruni: Jurnal Ilmiah Pendidikan Fisika, 4(1). 
Jazilah, N., Fasya, A. G., Ningsih, R., \& Abtokhi, A. (2014). Uji Toksisitas Ekktrak Daun Binahong Terhadap Larva Udang Artemia Salina Leach Dengan Metode Brine Shrimp Lethality Test. Alchemy: Journal Of Chemistry, O(1), 118-124.

Rimporok, S., Kepel, B. J., \& Siagian, K. V. (2015). Uji Efektivitas Ekstrak Daun Binahong (Anredera Cordifolia Steenis) Terhadap Pertumbuhan Streptococcusmutans Secara In Vitro. Pharmacon Jurnal Ilmiah Farmasi, 4(4).

Roslizawaty, Ramadani, N. Y., Fakhrurrazi, \& Herrialfian. (2013). Aktivitas Antibakterial Ekstrak Etanol Dan Rebusan Sarang Semut (Myrmecodia Sp.)TerhadapBakteri Escherichia coli. Jurnal Medika Veterinaria, 7(2).

Silalahi, Y. C. E., Sari, I., Siregar, S., Sinaga, D. R., \& Matari, M. (2016). Pengujian Antibakteri Bedak Dingin Herbal Mahkota Dewa Terhadap Bakteri Penyebab Jerawat. Jurnal Farmanesia, 11(11).

Umar, A., Krihariyani, D., \& Mutiarawati, D. T. (2012). Pengaruh Pemberian EkstrakDaun Binahong (Andredera cordifolia(TEN) steenis) Terhadap Kesembuhan LukaInfeksi Staphylococcus aureus Pada Mencit. Analisis Kesehatan Sains, 1(2). 